Journal of Thermal Engineering, Vol. 6, No. 4, pp. 438-439, July, 2020

Yildiz Technical University Press, Istanbul, Turkey

\title{
PROFESSOR SOMCHAI WONGWISES ON HIS 60TH BIRTHDAY
}

\author{
Mohamed M. Awad ${ }^{1,{ }^{*}}$, Pranab Kumar Mondal ${ }^{2}$, Omid Mahian ${ }^{3}$, Ho Seon Ahn ${ }^{4}$, Ahmet Selim Dalkiliç ${ }^{5}$, Ioan \\ Pop $^{6}$, Dieter Mewes ${ }^{7}$, Adrian Bejann ${ }^{8}$, Bahri Şahin ${ }^{9}$
}

\section{In Honor of Professor Somchai Wongwises on His 60th Anniversary}

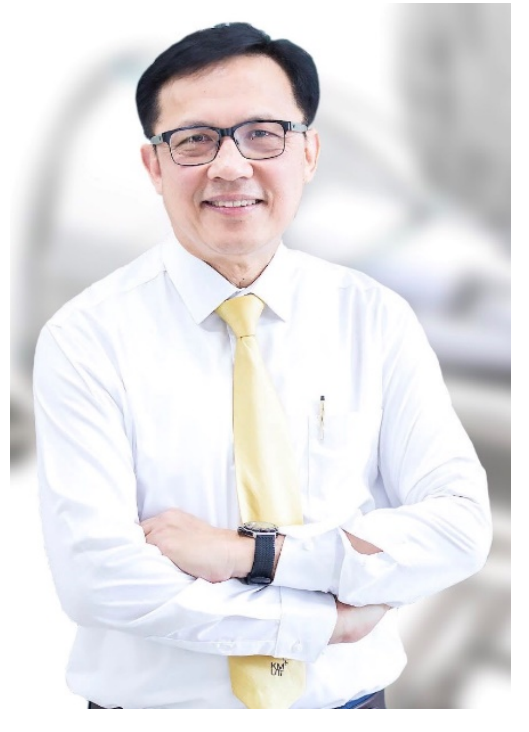

Professor Somchai Wongwises is one of the well-known names in the fields of two-phase flow, and heat transfer enhancement. Professor Somchai Wongwises was born on the $3^{\text {rd }}$ October 1959 in Bangkok, Thailand. He received his B.Sc. in Bachelor of Engineering (with honors) in Mechanical Engineering, Faculty of Engineering, King Mongkut's University of Technology Thonburi (KMUTT), Bangmod, Bangkok, Thailand in 1982. Then, he transferred to the Asian Institute of Technology (AIT), Khlong Luang, Pathum Thani, Thailand to prepare for a Master's Degree in Energy Technology that was awarded in August 1984. Subsequently, he obtained a Ph.D. in Mechanical Engineering from Chulalongkorn University, Bangkok, Thailand in 1989. He received his Doktor Ingenieur (Dr.-Ing.) in Mechanical Engineering from Institute of Process Engineering, University of Hannover, Hannover, Germany in August 1994 under the supervision of Professor Dr.-Ing. Dieter Mewes. With greatly appreciated scholarships from DAAD (German Academic Exchange Service) and from the University of Hannover, his research work in Germany was crowned with complete success.

He started his engineering career in 1985 as a project engineer at Jalaprathan Cement Co, Ltd. Later, he joined the Department of Mechanical Engineering, KMUTT as a lecturer in 1987, teaching undergraduate and graduate courses. He became assistant professor in 1990. After obtaining his Dr.-Ing. from Germany in 1994, he returned back to KMUTT where he rose to associate professor in 1996. Four years later, he was promoted to a full professor in 2000. He is the head of the Fluid Mechanics, Thermal Engineering and Multiphase Flow Research Laboratory (FUTURE). In addition, he is a member of the academy of science, the royal society of Thailand.

During his academic life at KMUTT, Professor Somchai Wongwises has published many papers on gas-liquid two phase flow, heat transfer enhancement, refrigeration and air-conditioning, and thermal system design like Refs. [110]. Professor Somchai Wongwises had served as Former Editor of Experimental Thermal and Fluid Science. Currently, he is an associate editor of Journal of Thermal Analysis and Calorimetry [11] and regional editor of Journal of Thermal Engineering [12].

This paper was recommended for publication in revised form by Regional Editor Ahmet Selim Dalkilic

${ }^{1}$ Mechanical Power Engineering Department, Faculty of Engineering, Mansoura University, Mansoura, Egypt 35516

${ }^{2}$ Microfluidics and Microscale Transport Processes Laboratory, Department of Mechanical Engineering, Indian Institute of Technology Guwahati, Guwahati 781039, India

${ }^{3}$ School of Chemical Engineering and Technology, Xi'an Jiaotong University, Xi'an, Shaanxi 710049, China

${ }^{4}$ Department of Mechanical Engineering, Faculty of Engineering, Incheon National University, Incheon, Republic of Korea

${ }^{5}$ Department of Mechanical Engineering, Faculty of Mechanical Engineering, Yildiz Technical University, Yildiz, Besiktas, Istanbul, 34349, Turkey

${ }^{6}$ Department of Mathematics, Faculty of Mathematics and Computer Science, Babeş-Bolyai University, 400084 Cluj-Napoca, CP 325, Romania

${ }^{7}$ Process Engineering, Faculty of Mechanical Engineering, Leibniz University Hannover, Callinstr. 36, 30617 Hannover, Germany ${ }^{8}$ Department of Mechanical Engineering and Materials Science, Pratt School of Engineering, Duke University, Durham, NC 27708-0300, USA

${ }^{9}$ Department of Naval Architecture and Marine Engineering, Naval Architecture and Maritime Faculty, Yildiz Technical University, Yildiz, Besiktas, Istanbul, 34349, Turkey

*E-mail address: $m \_m \_a w a d @ m a n s . e d u . e g$

Orcid id: 0000-0001-6238-5872, 0000-0002-9368-1532, 0000-0001-9996-8246, 0000-0002-1036-3038, 0000-0002-5743-3937, 00000002-0660-6543, 0000-0002-3849-6289, 0000-0002-2419-2698, 0000-0002-3885-9588

Manuscript Received 6 June 2020, Accepted 6 June 2020 
Professor Somchai Wongwises is the recipient of many awards such as TRF Senior Research Scholar in Engineering from the Thailand Research Fund (TRF) in 2003, National Distinguished Researcher Award in Engineering and Research Industry from the National Research Council of Thailand (NRCT) in 2004, TRF Senior Research Scholar in Engineering from the Thailand Research Fund (TRF) in 2006, Outstanding Scientist Award from the Foundation for the Promotion of Science and Technology under the Patronage of His Majesty the King in 2006, Outstanding TRF Research Output in 2006, The Dushdi Mala in Engineering in 2008, National Outstanding Professor in Science and Technology from the Council of University Faculty Senate of Thailand in 2009, Outstanding Professor in Academic and Research Performance in the $48^{\text {th }}$ Anniversary of King Mongkut's University of Technology Thonburi in 2009, Outstanding Research Professor from The Thailand Research Fund (TRF) in 2010, Outstanding Alumni of Asian Institute of Technology (AIT) in 2011, National Outstanding Person in Science and Technology from Office of the Prime Minister in 2011, NSTDA Research Chair Grant from The National Science and Technology Development Agency (NSTDA) in 2013, Outstanding TRF Research Output in 2014, Thailand Frontier Author Award from Thomson Reuter in 2015, Outstanding Alumni of King Mongkut's University of Technology Thonburi in 2015, NSTDA Research Chair Grant from the National Science and Technology Development Agency (NSTDA) in 2019, The National Fatherhood Award in 2019, and Highly Cited Researcher from Clarivate Analytics in 2017, 2018, 2019 [13].

On the occasion of his $60^{\text {th }}$ birthday, on behalf of his friends, colleagues, and students all over the globe, we wish Professor Somchai Wongwises a continuous active life in good health and happiness and a very happy birthday!

\section{References}

[1] Trisaksri V, Wongwises S. Critical review of heat transfer characteristics of nanofluids. Renew Sustain Energy Rev 2007. https://doi.org/10.1016/j.rser.2005.01.010.

[2] Daungthongsuk W, Wongwises S. A critical review of convective heat transfer of nanofluids. Renew Sustain Energy Rev 2007. https://doi.org/10.1016/j.rser.2005.06.005.

[3] Trisaksri V, Wongwises S. Nucleate pool boiling heat transfer of TiO2-R141b nanofluids. Int J Heat Mass Transf 2009. https://doi.org/10.1016/j.ijheatmasstransfer.2008.07.041.

[4] Dalkilic AS, Wongwises S. New experimental approach on the determination of condensation heat transfer coefficient using frictional pressure drop and void fraction models in a vertical tube. Energy Convers Manag 2010. https://doi.org/10.1016/j.enconman.2010.05.019.

[5] Duangthongsuk W, Wongwises S. An experimental study on the heat transfer performance and pressure drop of TiO2-water nanofluids flowing under a turbulent flow regime. Int $\mathrm{J}$ Heat Mass Transf 2010. https://doi.org/10.1016/j.ijheatmasstransfer.2009.09.024.

[6] Mahian O, Kianifar A, Heris SZ, Wen D, Sahin AZ, Wongwises S. Nanofluids effects on the evaporation rate in a solar still equipped with a heat exchanger. Nano Energy 2017. https://doi.org/10.1016/j.nanoen.2017.04.025.

[7] Saisorn S, Wongpromma P, Wongwises S. The difference in flow pattern, heat transfer and pressure drop characteristics of mini-channel flow boiling in horizontal and vertical orientations. Int J Multiph Flow 2018. https://doi.org/10.1016/j.ijmultiphaseflow.2018.01.005.

[8] Mahian O, Kolsi L, Amani M, Estellé P, Ahmadi G, Kleinstreuer C, et al. Recent advances in modeling and simulation of nanofluid flows-Part I: Fundamentals and theory. Phys Rep 2019. https://doi.org/10.1016/j.physrep.2018.11.004.

[9] Mahian O, Kolsi L, Amani M, Estellé P, Ahmadi G, Kleinstreuer C, et al. Recent advances in modeling and simulation of nanofluid flows-Part II: Applications. Phys Rep 2019. https://doi.org/10.1016/j.physrep.2018.11.003.

[10] Ahn HS, Kim KM, Lim ST, Lee CH, Han SW, Choi H, et al. Anti-fouling performance of chevron plate heat exchanger by the surface modification. Int J Heat Mass Transf 2019. https://doi.org/10.1016/j.ijheatmasstransfer.2019.118634.

[11] Journal of Thermal Analysis and Calorimetry n.d. https://www.springer.com/journal/10973/editors.

[12] Journal of Thermal Engineering n.d. http://www.eds.yildiz.edu.tr/journal-of-thermalengineering/EditorialBoard.

[13] Spotlight: Highly Cited Researcher Somchai 2020. https://clarivate.com/webofsciencegroup/article/spotlight-highly-cited-researcher-somchai-wongwises/. 